\section{OVERVIEW OF THE SHIP EFFICIENCY MANAGEMENT PLAN FOR A SEAFARING MODEL SHIP BASED ON THE IMO MEPC 231 (65) RESOLUTION}

DOI 10.2478/ntpe-2018-0079

\author{
Assoc. Prof. PhD. Aleksandr Waliszyn \\ Assoc. Prof. PhD. Andrzej Adamkiewicz \\ Maritime University of Szczecin, Poland \\ PhD. Abdurashid Yafasov \\ Kaliningrad State University, Russia
}

Volume 1

Issue 1

pp. $631-637$

\begin{abstract}
The increase of maritime international trade, especially of dangerous liquid cargos led to a significant increase of the number of sea-going ships. Their operation poses a real threat to the maritime environment both as a result of terminal events with transported dangerous liquid cargos and emissions of harmful products from fuels burnt by ship power systems. Because of those there is a need to undertake actions to prevent such occurrences using formal, legal and utilitarian tools. Philosophy of research methodology and rationalization of actions in compliance with international directives have been shown. The article presents the guidelines of the IMO Resolution MEPC 231(65) on preventing air pollution with carbon dioxide from ships. Design Energy Efficiency Index (EEDI) for a new ship was given as well as Energy Efficiency Operational Indicator (EEOI) determined for conventional ships after a completed voyage was defined and interpreted. A model of a Ship Energy Efficiency Management Plan (SEEMP) of a chosen ship has been constructed taking into account possible actions aimed at obtaining the highest power efficiency of the ship at sea voyage. Conclusions have been drawn and possible directions of further actions have been established.
\end{abstract}

Keywords: International Maritime Organization (IMO), IMO Resolution MEPS 231 (65), Design Energy Efficiency Index for a New Ship (EEDI) Operational Indicator Energy Efficiency Index (EEOI), $\mathrm{CO}_{2}$ Emission Index Cf, Energy Efficiency Management Plan (SEEMP)

\title{
INTRODUCTION
}

The increase of international trade in the last years of the twentieth and at the beginning of the twenty-first century led to a significant increase of the number of seagoing ships carrying goods as according to IMO $80 \%$ of the bulk cargo is transported by sea (Walczak, 2018). Obviously such amounts of goods most of which are liquid, i.e. crude oil and its products as well as other chemicals and gases may have a negative impact on marine environment.

International Maritime Organisation (IMO) was set up as a committee of the United Nations and since its beginnings it has always aimed to increase the safety level of marine navigation and prevent ships from polluting seas. IMO is a a UN agency, to which belong 169 countries from the whole world, setting up regulations within sea legislature that are valid all over world. It determines the best possible attitude aiming at ensuring safe and clean sea navigation in the competitive environment of global industry (Walczak A. 2018). An example of such activities is the implementation of International Convention on "Protection against sea pollution by ships", called The Marpol Convention, and "International Code of Safe Ship Operation Management and Pollution Prevention", called the "ISM Code", into global marine navigations (PRS 2018), (Herdzik, 2017).

\section{METHODOLOGY OF RESEARCH}

Aiming at reaching its main goal i.e. the increase of sea navigation safety and protection against sea pollution caused by ships, IMO basing on the MEPS 203 (62) resolution introduced changes into the MARPOL Convention which came into power on the $1^{\text {st }}$ January 2013 and on its basis all ships of DWT 400 tons and more must have their Ship Energy Efficiency Management Plan (SEEMP) (IMO 2012A) (Adamkiewicz and Anczykowska, 2017). The aim of implementing that 
resolution is to lower the emissions of greenhouse gases, that is carbon dioxide $\left(\mathrm{CO}_{2}\right)$ (Adamkiewicz and Przybyła, 2017). In Appendix 6 to the MARPOL Convention, a new chapter, Chapter 4, was introduced. It contains regulations on ship energy efficiency (IMO 2012B). These regulations came into power on 1st January 2013 and refer to all conventional ships navigating internationally. In order to evaluate the efficiency of SEEMP, the MEPS 203 (62) resolution recommends the use of two indicators: Design Energy Efficiency Index (EEDI) for new ships or those that were completely rebuilt and Energy Efficiency Operational Indicator (EEOI) determined for MEiconventional ships still in operation (Polish Register of Shipping, 2017), (IMO MEPC 231 (61) Resolution), (IMO MEPC 212 (63) Resolution), (IMO MEPC 214 (63) Resolution) (Adamkiewicz and Zeńczak, 2016)

EEDI obtained for a new ship is a measurement of ship energy efficiency $[\mathrm{g} /(\mathrm{t} \mathrm{nm})]$ and is calculated from the following formula (IMO 2012A) (Mundt and Köpke, 2011):

where:

$$
E E D I=3.1144 \cdot \frac{190 \cdot \sum_{i=1}^{N M E} P_{M E i}+215 P_{A E}}{70 \% D W T \cdot V_{r e f}}
$$

$P_{M E}$ - power of the main engine $[\mathrm{kW}]$

$P_{A E}$ - power of auxiliary engines $[\mathrm{kW}]$

$N$ - number of engines

$P_{M E i}$ - engine power equal to $75 \%$ of the nominal power of the installed engine

$D W T$ - register ton

$V_{\text {ref }}$ - reference speed

$E E D /$ for a designed ship is the value which is calculated from the following relationship:

$E E D I=\left(\right.$ estimated $\mathrm{CO}_{2}$ emission at an estimated consumption of fuel)/(ship capability to transport cargo) $\cdot$ (distance covered) in $\left[\mathrm{g} \mathrm{CO}_{2} / \mathrm{t} \cdot \mathrm{Mm}\right]$

where:

$\mathrm{Mm}$ - sea mile

EEOI is determined for a ship after it completes its voyage. It requires the knowledge of the amount of fuel consumed during the voyage by all energy equipment on the ship, distance covered by the ship and transport effects ( amount of cargo in tons, number of TEUs, number of passengers etc. in relation to the type of the ship). Generally the aim is to determine the amount of emitted $\mathrm{CO}_{2}$ needed to transport $\mathrm{i}$ a ton of cargo over the distance of 1 kilometer or 1 sea mile e.g. [g CO$/ 2 / \mathrm{ton}^{*} \mathrm{~km}$ ] (Perera, Mo 2016). The relation to determine EEOI is as follows:

$\mathrm{EEOI}=\left[\right.$ amount of consumed fuel $\mathrm{C}_{\mathrm{f}} /$ cargo mass $\cdot$ distance covered

where:

$\mathrm{C}_{\mathrm{f}}-\mathrm{CO}_{2}$ emission coefficient $\left[\mathrm{kgCO}_{2} / \mathrm{kg}\right.$ of fuel]

\section{RESULTS}

Values of $\mathrm{CO}_{2}$ coefficient for different kinds of fuel are given in Table 1 (Adamkiewicz et al., 2016).

Table 1.

Carbon content In marine fuels and $\mathrm{CO}_{2}$ emission coefficient.

\begin{tabular}{|c|c|c|c|}
\hline Kind of marine fuel & Symbol & $\begin{array}{l}\text { Carbon content } \\
\text { (averaged) }\end{array}$ & $\begin{array}{c}\mathrm{CO}_{2} \text { emission } \\
\text { coefficient } \mathrm{C}_{\mathrm{f}} \\
\mathrm{kg} \mathrm{CO} / \mathrm{kg} \text { of fuel }\end{array}$ \\
\hline Distilate oil or gas & $\begin{array}{l}\text { ISO } 8217 \text { od } \\
\text { DMX do DMB }\end{array}$ & 0.8744 & 3.206 \\
\hline Light fuel oil & ISO 8217 od RMA do RMD & 0.8594 & 3.151 \\
\hline Heavy fuel oil & ISO 8217 od RME do RMK & 0.8493 & 3.1144 \\
\hline Propane & LPG & 0.8182 & 3.000 \\
\hline Butane & LPG & 0.8284 & 3.030 \\
\hline Methane & LPG, CNG & 0.7500 & 2.750 \\
\hline
\end{tabular}

SEEMP is a part of a company's general system of management of energy efficiency and as such it should be treated as an integral element of wider systems of company management. It assists 
the crew in current supervision of ship's energy efficiency and minimization of costs. Relying on the best practice it expects that it can be done within ordinary routine activities of the crew without excessive administrative pressure on their time. SEEMP complies with the requirements of IMO 231 (65) resolution and comprises key processes required for continuous optimization of energy consumption with the view to minimize costs (PRS 2018).

To obtain the best results in ship energy efficiency management it is necessary to list a few key issues that have to be evaluated and supervised continuously or periodically and for these issues the following should be carried out: determination of aims, operational management, technical management, reporting and supervision, supervision, analysis and evaluation.

Effective operational management and effective supervision of these activities leads to the biggest energy savings and thus increases ship energy efficiency. The following fields possess the greatest potential capabilities:

- effective activities regarding fuel consumption,

- improving voyage planning, faultless consideration for hydro-meteorolgical conditions, scheduling ship's arrival on time (without unnecessary reserves),

- optimization of ship servicing - optimization of trimming, optimization and scheduling of operations connected with ship ballasting,

- proper use of autopilot,

- proper fleet management:

O effective use of capacities of particular ships,

0 rationalization of operations connected with loading,

$\bigcirc$ shortening the time of staying in ports and lowering fuel consumption al loading operations.

\section{DISCUSSION}

To achieve the results of the best practice within energy management, energy efficiency and efficiency aims, goals should be determined basing on the implemented means referring to energy efficiency. These aims are later used for comparative analysis and evaluation of effectiveness of the applied means. Wherever it is possible, aims are quantitative and based on time. Review and evaluation of effects takes place periodically at a planned date. Review of SEEMP management and evaluation is carried out periodically. Changes in regulations and procedures of self-evaluations of SEEMP are the responsibility of the ship-owner's headquarters.

Effective technical management ensures that technical equipment of the ship and power systems are in good technical condition and enable significant energy savings. The following fields comprise the main potential possibilities (Adamkiewicz and Cydejko, 2015):

- ship hull: preventing hull overgrowing, usage of special paints, cleaning the surfaces of propeller blades,

- ship main power system - technical condition and operational parameters of the main engine, optimization of energy states of machinery facilities,

- auxiliary facilities - condition and performance of auxiliary facilities (current generating units, boilers, system for waste heat recovery),

- fuel: usage of high quality fuels, operating facilities for fuel treatment.

An example of a Ship Energy Efficiency Management Plan (SEEMP) is shown in Table 2.

Table 2.

An example of a Ship Energy Efficiency Management Plan (SEEMP).

\begin{tabular}{|l|l|l|l|}
\hline Number & $\begin{array}{c}\text { Measures } \\
\text { for effective fuel } \\
\text { consumption }\end{array}$ & \multicolumn{1}{|c|}{ Operations } & \multicolumn{1}{c|}{$\begin{array}{c}\text { Person } \\
\text { responsible }\end{array}$} \\
\hline & & $\begin{array}{l}\text { Department of planning and } \\
\text { loading operations prepares a } \\
\text { loading schedule together with } \\
\text { basic information regarding the } \\
\text { ship, such as speed from port to } \\
\text { port - ETA to the next port }\end{array}$ & $\begin{array}{l}\text { Department of planning } \\
\text { and loading operations }\end{array}$ \\
\hline
\end{tabular}




\begin{tabular}{|c|c|c|c|}
\hline 1. & $\begin{array}{l}\text { Optimization and } \\
\text { rationalization of ship } \\
\text { speed and times of } \\
\text { staying }\end{array}$ & $\begin{array}{l}\text { Range - reduction of time when } \\
\text { the ship is anchored or drifting } \\
\text { and entering the port at the time } \\
\text { given for loading operations } \\
\text { Recording - midday reports, } \\
\text { MARORKA system } \\
\text { Supervision - monthly reports on } \\
\text { fuel and lubricant consumption, } \\
\text { length of sea routs - comparison } \\
\text { with routs of other ship owners } \\
\text { Deadline - continuous supervision } \\
\text { and continuous improvements }\end{array}$ & $\begin{array}{l}\text { Ship captain } \\
\text { Supervisory centre }\end{array}$ \\
\hline 2. & $\begin{array}{l}\text { Voyage planning } \\
\text { Weather consideration }\end{array}$ & $\begin{array}{l}\text { Choice of the most advantageous } \\
\text { rout considering winds, sea } \\
\text { currents, weather conditions, state } \\
\text { of the sea before and during the } \\
\text { voyage } \\
\text { Range - implementation of } \\
\text { systems for predicting and } \\
\text { monitoring the weather } \\
\text { Recording - midday reports, } \\
\text { MARORKA system, AWT reports } \\
\text { Supervision - periodical reviewing } \\
\text { of the above reports and checking } \\
\text { implementation correctness during } \\
\text { navigational audits } \\
\text { Deadline - continuous supervision } \\
\text { and continuous improvements }\end{array}$ & $\begin{array}{l}\text { Ship captain } \\
\text { Sea department of the } \\
\text { headquarters } \\
\text { Ship owner's supervisory } \\
\text { centre }\end{array}$ \\
\hline 3. & Trim optimization & $\begin{array}{l}\text { Suggesting optimum trim for } \\
\text { different states of ship draft and } \\
\text { voyaging with a suggested trim } \\
\text { and determination of ship power } \\
\text { efficiency at different trims at the } \\
\text { same draft } \\
\text { Range - implementation of the } \\
\text { already optimized trim (results } \\
\text { from practice) to obtain minimum } \\
\text { values of ship hull resistance } \\
\text { Recording - monthly reports, } \\
\text { voyage reports, MARORKA } \\
\text { system } \\
\text { Supervision - comparison of } \\
\text { achieved power efficiency with } \\
\text { those of other ships of the fleet } \\
\text { Deadline - continuous supervision } \\
\text { and continuous improvements }\end{array}$ & $\begin{array}{l}\text { Department of planning } \\
\text { and loading operations } \\
\text { Ship captain } \\
\text { Fleet supervision centre }\end{array}$ \\
\hline 4. & $\begin{array}{l}\text { Optimization of the hull } \\
\text { condition }\end{array}$ & $\begin{array}{l}\text { Range - underwater clearing of } \\
\text { the hull and the propeller when } \\
\text { hull energy efficiency decreases } \\
\text { below an indicated value (hull } \\
\text { resistance increases above the } \\
\text { permitted value) } \\
\text { Recording - divers' reports, } \\
\text { MARORKA system, monthly } \\
\text { technical reports }\end{array}$ & $\begin{array}{l}\text { Chief mechanic } \\
\text { Technical department } \\
\text { of the headquarters } \\
\text { Fleet supervision centre }\end{array}$ \\
\hline
\end{tabular}




\begin{tabular}{|c|c|c|c|}
\hline & & $\begin{array}{l}\text { Supervision - evaluation of ship } \\
\text { hull condition on the basis } \\
\text { of the above mentioned reports } \\
\text { Deadline - continuous supervision } \\
\text { and continuous improvements }\end{array}$ & \\
\hline 5. & $\begin{array}{l}\text { Maintenance } \\
\text { of technical condition } \\
\text { of the underwater Hull } \\
\text { and propeller blades }\end{array}$ & $\begin{array}{l}\text { Range - underwater clearing } \\
\text { of the hull and the propeller when } \\
\text { hull energy efficiency decreases } \\
\text { below an indicated value (hull } \\
\text { resistance increases above } \\
\text { the permitted value) } \\
\text { Recording - divers' reports, } \\
\text { MARORKA system, monthly } \\
\text { technical reports }\end{array}$ & $\begin{array}{l}\text { Ship captain } \\
\text { Chief engineer } \\
\text { Fleet supervision centre } \\
\text { Department } \\
\text { of environmental } \\
\text { protection management }\end{array}$ \\
\hline 6. & $\begin{array}{l}\text { Supervision of the main } \\
\text { engine fuel } \\
\text { consumption } \\
\text { and analysis of its } \\
\text { operational parameters }\end{array}$ & $\begin{array}{l}\text { Range - continuous supervision } \\
\text { of the main engine fuel } \\
\text { consumption and periodical } \\
\text { checking of the main engine } \\
\text { performance } \\
\text { Reporting - daily reports, monthly } \\
\text { reports and voyage reports } \\
\text { Supervision - continuous SFOC } \\
\text { supervision of the main engine } \\
\text { Deadline - continuous supervision } \\
\text { and continuous improvements }\end{array}$ & $\begin{array}{l}\text { Chief engineer } \\
\text { Ship captain } \\
\text { Technical department } \\
\text { of the headquarters } \\
\text { Fleet supervision centre }\end{array}$ \\
\hline 7. & $\begin{array}{l}\text { Management of ship } \\
\text { electrical energy }\end{array}$ & $\begin{array}{l}\text { Preventing current generating } \\
\text { units from operating at low loads } \\
\text { and aiming at reducing the } \\
\text { number of operating units(apart } \\
\text { from the situation when operations } \\
\text { of many units is required - e.g. } \\
\text { port manouvering, canal } \\
\text { manouvering etc.) } \\
\text { Range - optimization of the ship } \\
\text { power plant within energy } \\
\text { efficiency and ship safety } \\
\text { Recording - daily reports, monthly } \\
\text { technical reports, voyage reports } \\
\text { MARORKA system (online) } \\
\text { Supervision - evaluation of ship } \\
\text { hull condition on the basis of the } \\
\text { above mentioned } \\
\text { Deadline - continuous supervision } \\
\text { and continuous improvements }\end{array}$ & $\begin{array}{l}\text { Chief engineer } \\
\text { Fleet supervision centre }\end{array}$ \\
\hline 8. & $\begin{array}{l}\text { Management of ship } \\
\text { heating energy (heat } \\
\text { and steam) }\end{array}$ & $\begin{array}{l}\text { Limiting to the highest extent } \\
\text { the use of fire boilers } \\
\text { and replacing them with } \\
\text { waste-heat ones } \\
\text { Range - optimization } \\
\text { of operations of facilities } \\
\text { generating heating steam } \\
\text { regarding fuel consumption } \\
\text { Recording - daily reports, monthly } \\
\text { technical reports }\end{array}$ & $\begin{array}{l}\text { Chief engineer } \\
\text { 2nd engineer officer }\end{array}$ \\
\hline
\end{tabular}




\begin{tabular}{|c|c|c|c|}
\hline & & $\begin{array}{l}\text { Supervision - continuous } \\
\text { supervision of facilities generating } \\
\text { heating steam } \\
\text { Deadline - continuous supervision } \\
\text { and continuous improvements }\end{array}$ & \\
\hline 9. & $\begin{array}{l}\text { Managing electrical } \\
\text { energy }\end{array}$ & $\begin{array}{l}\text { Switching-off lights in communal } \\
\text { areas and In cabins when not In } \\
\text { use. Using energy saving bulbs } \\
\text { Range - lowering energy } \\
\text { consumption throughout correct } \\
\text { supervision of lighting systems } \\
\text { Supervision - continuous } \\
\text { supervision performed by the ship } \\
\text { management } \\
\text { Deadline - continuous supervision } \\
\text { and continuous improvements }\end{array}$ & $\begin{array}{l}\text { Ship captain } \\
\text { Chief engineer } \\
1^{\text {st }} \text { navigating officer } \\
1^{\text {st }} \text { engineer officer } \\
\text { 2nd engineer officer }\end{array}$ \\
\hline 10. & $\begin{array}{l}\text { Training within quality } \\
\text { management and } \\
\text { supervision of ship } \\
\text { energy efficiency }\end{array}$ & $\begin{array}{l}\text { Crew training within SEEMP } \\
\text { and CEEMP as well as } \\
\text { enlargement of the knowledge } \\
\text { and operational culture } \\
\text { of the crew } \\
\text { Range - organizing periodical } \\
\text { training within SEEMP } \\
\text { and CEEMP and their application } \\
\text { on a ship Recording - training } \\
\text { reports } \\
\text { Supervision - analysis of training } \\
\text { reports, constant supervision } \\
\text { performed by ship management } \\
\text { Deadline - continuous supervision } \\
\text { and continuous improvements }\end{array}$ & $\begin{array}{l}\text { Ship captain } \\
\text { Chief engineer } \\
1^{\text {st }} \text { navigating officer } \\
1^{\text {st }} \text { engineer officer } \\
\text { 2nd engineer officer } \\
\text { Fleet supervision centre }\end{array}$ \\
\hline
\end{tabular}

\section{CONCLUSION}

The presented overview of Ship Energy Efficiency Management Plan (SEEMP) can be treated as a model one in compliance with the requirements of the IMO 231 (65) Resolution. It shows that issues connected with protection against air pollution caused by ships are of interest not only to IMO. Monitoring implementation and realization of SEEMP on seagoing vessels is the duty port administrations and Classification Societies. In recent years European Agency for Safety on Seas (EMSA) has considered reduction of greenhouse gas emissions from seagoing ships as a serious challenge for the ship industry. EMSA evaluates, supports and helps all monitoring institutions which meet the requirements of IMO 231 (65) (IMO 2013). Resolution throughout carrying out research, checking the quality of bunker fuel in European Union ports and on board ships (Blanco-Davis, Zhou, 2016). Workshops are regularly organized in which national administrations of member countries take part in order to ensure progress and solve problems connected with implementation of rules regarding emissions of harmful sulphur and nitrogen compounds from ships into the atmosphere.

\section{REFERENCES}

Adamkiewicz, A., Anczykowska A. (2017). LNG okrętowym paliwem przyszłości w basenie Morza Bałtyckiego. Przegląd Gazowniczy, 1, pp. 18-21.

Adamkiewicz, A., Bartoszewski, M., Kendra, M. (2016). Analysis of Consequences of Using Gas Fuels for Running Auxiliary Ship Boilers in The Light of Contemporary Environmental Protection Requirements. Management Systems in Production Engineering, 3(23), pp. 183190.

Adamkiewicz, A., Cydejko, J. (2015). Analiza układów napędowych zbiornikowców LNG w aspekcie spełnienia wymagań strefy kontroli emisji spalin. Rynek Energii, 3(118), pp. 80-86. 
Adamkiewicz, A., Przybyła, M. (2017). A Concept of a Marine Power Plant Supplied With Natural Gas With A Reduced $\mathrm{CO}_{2}$ Emission Index. Journal of Machine Construction and Maintenance, 3(106), pp. 75-82.

Adamkiewicz, A., Zeńczak, W. (2016) Methanol As An Ecological Fuel For Sea-Going Vessels. Fachhochschule Stralsund: Symposium Nutzung Regenerativer Energiequellen Und Wasserstofftechnik Stralsund., 22, pp. 170-174.

Blanco-Davis, Z. (2016). Life Cycle Assessment as a complementary utility to regulatory measures of shipping energy efficiency. Ocean engineering, 128, pp. 94-104.

Herdzik, J. (2017). Uwagi do eksploatacyjnego wskaźnika efektywności energetycznej statku. Autobusy N6, pp. 209-213.

IMO (2012A): Guidelines on the Method of Calculation of the Attained Energy Efficiency Design Index (EEDI) for New Ships, Avaiable at: http://www.imo.org [Accessed: May 2018].

IMO (2012B): Guidelines on Survey and Certification of the Energy Efficiency Design Index (EEDI), Avaiable at: http://www.imo.org [Accessed: May 2018].

IMO (2013): Guidelines for Calculation of Reference Lines for Use with the Energy Efficiency Design Index (EEDI), Avaiable at: http://www.imo.org [Accessed: May 2018]

Mundt, T, Köpke, M. (2011). MEPC 62: Energy Efficiency Design Index verabschiedet, Schiff \& Hafen, 9, pp 12-15.

Perera, M. (2016): Emission control based energy efficiency measures in ship operations. Applied Ocean Research, 60, pp 29-46.

PRS (2018): Wytyczne Dotyczące Efektywności Energetycznej Statków, Avaiable at: https://www.prs.pl [Accessed: April 2018].

Walczak, A. (2018). Moja międzynarodowa służba morska. Szczecin: Zakład Usług Poligraficznych i Wydawniczych s.c.

Date of submission of the article to the Editor: 05/2018

Date of acceptance of the article by the Editor: 09/2018 